\title{
WHO 2016 Definition of Chronic Myeloid Leukemia and Tyrosine Kinase Inhibitors
}

\author{
Kronik Myeloid Lösemi WHO 2016 Tanımlaması ve Tirozin Kinaz Inhibitörleri
}

(D) Ibrahim C. Haznedaroğlu1, (D) Işınsu Kuzu2, (D) Osman İlhan3

1 Hacettepe University Faculty of Medicine, Department of Hematology, Ankara, Turkey

${ }^{2}$ Ankara University Faculty of Medicine, Department of Pathology, Ankara, Turkey

${ }^{3}$ Ankara University Faculty of Medicine, Therapeutic Apheresis Unit, Department of Hematology, Ankara, Turkey

\section{Abstract}

Philadelphia $\left(\mathrm{Ph}^{*}\right) / \mathrm{BCR}-\mathrm{ABL} 1-$ positive chronic myeloid leukemia $(\mathrm{CML})$ is considered as a chronic life-long disease, which could be manageable with tyrosine kinase inhibitor (TKI) drugs. The aim of TKI drug treatment is to provide age- and sex-matched duration of life in a given patient with CML. Personalized CML treatment with TKI drugs is the key strategy. Individual treatment approach includes the harmonization of CML disease characteristics, clinical experience, and best available clinical evidence. Specific CML disease characteristics in a given patient include; $C M L$ disease risk, comorbidities, molecular profile, compliance, lifestyle, and drug off-target risk profile. CML research evidence includes; randomized clinical trials indicating the data on the efficacy, safety, tolerability, toxicity, possible longterm adverse events, and pharmacoeconomy of TKIs. Clinical and physician experience includes TKI availability, TKI reimbursability, drug experience, adherence, and BCR-ABL1 monitorization facilities. The key decision of choosing a TKI of choosing TKIs for CML should be made via the consideration of these variables. The aim of this paper is to outline the latest 2016 World Health Organization definition of $\mathrm{CML}$ and its proper management with TKI-class drugs.

Keywords: Chronic myeloid leukemia, CML, Tyrosine kinase inhibitor, TKI

\begin{abstract}
III Öz

Philadelphia $\left(\mathrm{Ph}^{*}\right) / \mathrm{BCR}-\mathrm{ABL} 1(+)$ kronik myeloid lösemi (KML), tirozin kinaz inhibitörleri (TKI) grubundan ilaçlarla yaşam boyu yönetilebilecek kronik bir hastalıktır. TKi ilaç tedavisinin hedefi, herhangi bir KML hastasında aynı yaş ve cinsiyette sağlıklı bireylerde beklenen yaşam süresi idamesini sağlamak olmalıdır. KML tedavisinde bireyselleştirilmiş TKi ilaç kullanımı anahtar stratejidir. Bireysel tedavi yaklaşımı; KML hastalık özelliklerini, klinik deneyimi ve mevcut en iyi kanıtı uygunca birleştirme esaslıdır. Herhangi bir KML hastasında özgül hastalık özellikleri; KML hastalık riski, komorbiditeler, moleküler profil, hasta uyumu, yaşam tarzı, ve ilaç temelli yan etki profilleridir. KML'de kritik araştırma kanıtları; TKi etkinlik, güvenilirlik, tolerabilite, toksisite, uzun-dönem ilaç yan etkileri ve farmakoekonomi parametreleri için karar verdirici nitelikte olan randomize klinik çalışmalardır. Klinik ve hekim deneyimi; TKi mevcudiyeti, TKI geriödenebilirliği, ilaç deneyimi, ilaca uyum ve izleyen klinikte BCR-ABL1 izlem olanakları olarak özetlenebilir. KML seyrinde ana kritik TKI kararına esas olarak sayılan bu değişkenlerin dikkate alınması sonrasında ulaşıır. Bu makalenin amacı, KML tanımlamasında en son kullanılan Dünya Sağlık Örgütü-2016 kriterleri eşliğinde TKi grubu ilaçlar ile uygun KML yönetimi ilkelerini tartışmaktır.
\end{abstract}

Anahtar Sözcükler: Kronik myeloid lösemi, KML, Tirozin kinaz inhibitör, TKi

\section{Introduction}

Philadelphia $\left(\mathrm{Ph}^{*}\right) / \mathrm{BCR}-\mathrm{ABL} 1$-positive chronic myeloid leukemia $(\mathrm{CML})$ is a chronic neoplastic disease, which can be functionally cured via the administration of tyrosine kinase inhibitor (TKI) drugs [1]. The overall aim of TKI therapy in CML is to provide normal life duration and quality to the patient. The harmonization of CML disease characteristics, physician/clinic facilities, and best clinical evidence is vital to reach this ultimate aim $[2,3]$. The disease characteristics of a given patient include $\mathrm{CML}$ disease risk, comorbidities, molecular profile, compliance, lifestyle, and drug off-target risk profile. CML research evidence includes randomized clinical trials indicating data on the safety, efficacy, tolerability, toxicity, possible long-term adverse events, and pharmacoeconomy of TKIs. Clinical experience involves TKI availability, TKI reimbursability, drug experience, adherence, and

${ }^{\circ}$ Copyright 2020 by Turkish Society of Hematology

Turkish Journal of Hematology, Published by Galenos Publishing House

$\square+$ Address for Correspondence/Yazışma Adresi: İbrahim C. Haznedaroğlu, M.D., Hacettepe University Faculty of Medicine, Department of Hematology, Ankara, Turkey 
monitorization facilities. The critical decision regarding TKIs for CML should be done via the optimization of those variables for every single CML patient (Figure 1) [3]. The aim of this paper is to outline the proper TKI treatment for the management of CML, as described in the 2016 World Health Organization (WHO) classification [3].

\section{WHO Definition of Chronic Myeloid Leukemia}

The essential clinicopathological characteristics of $\mathrm{Ph}^{*}(+) \mathrm{CML}$ in the 2016 WHO classification are defined as follows [4];

\section{Chronic Phase CML}

This is a myeloproliferative neoplasm characterized by the chromosomal translocation $\mathrm{t}(9 ; 22)(\mathrm{q} 34.1 ; q 11.2)$, resulting in the BCR-ABL1 fusion gene and formation of the Philadelphia chromosome $\left(\mathrm{Ph}^{*}\right)$, which causes an increase in blood granulocytes and bone marrow myeloid precursors as the major proliferative component. Cryptic and variant forms of the Philadelphia chromosome as well as additional cytogenetic abnormalities may complicate the disease pathobiology. Therefore, interphase fluorescence in situ hybridization (FISH), chromosome banding analysis, and PCR should be integrated for the diagnosis and follow-up of CML $[5,6]$.

The disease is described in three main clinical phases, which were significantly prognostic before the TKI treatment era. The chronic phase is the initial phase. Disease progression is then described in two phases as the accelerated phase (AP) and blastic phase (BP). AP disease is characterized by 10\%-19\%

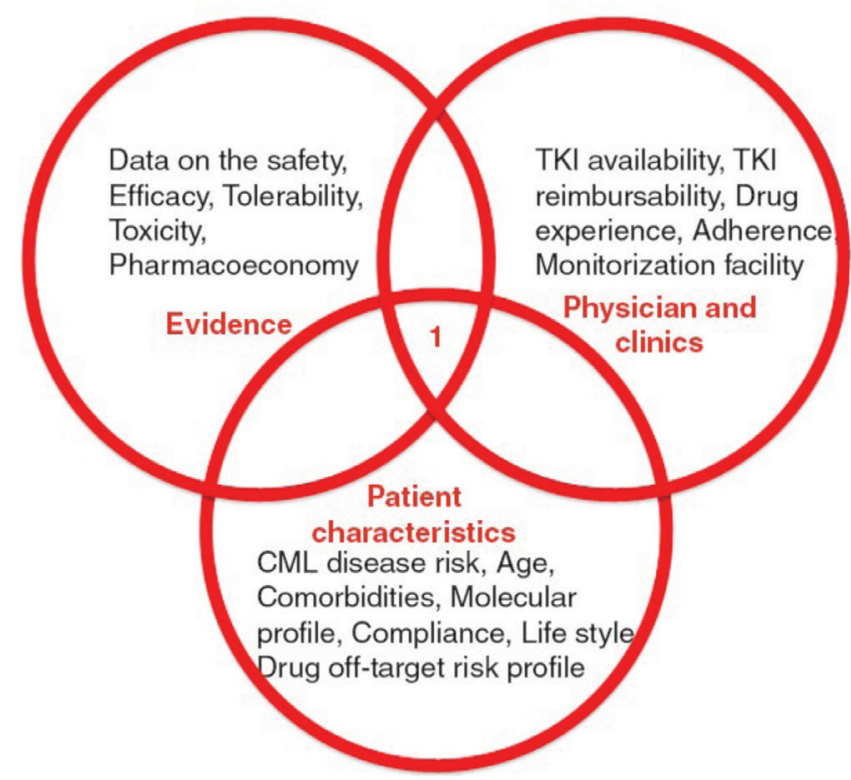

Figure 1. The harmonization of individual disease characteristics, the experience of physician/clinical facilities, and best clinical evidence is essential for clinical decision-making in chronic myeloid leukemia (CML).

CML: Chronic myeloid leukemia, TKI: Tyrosine kinase inhibitor. blasts in the bone marrow or peripheral blood. The criterion for transformed BP is more than 20\% blasts either in the blood or in the bone marrow, or at extramedullary sites [4].

Typical peripheral blood findings in CP-CML are characterized by increased neutrophils with various early-stage granulocytic precursors. The diagnosis needs to be proven by demonstrating the molecular abnormality of BCR-ABL1 fusion. Typical bone marrow (BM) histopathology is demonstrated in Figures 2A-2D.

The presence of $\mathrm{t}(9 ; 22)(q 34.1 ; q 11.2)$ or BCR-ABL1 abnormality could be demonstrated by karyotype analysis, FISH, or PCRbased methods. The most reliable and sensitive method is realtime PCR. This method is important and should be preferred especially for routine monitoring for the evaluation of the response to TKI treatment [7].

Complete responders to TKI treatment are defined by $<10 \times 109 / \mathrm{L}$ blood cell count and $<450 \times 109 / \mathrm{L}$ platelet count without any immature granulocytes in differentiation and nonpalpable spleen [4]. The bone marrow features and cellular compositions are normal with the appearance of erythrocytic precursors. Such a case is demonstrated in Figures $2 \mathrm{E}-2 \mathrm{H}$.

\section{Accelerated Phase CML}

The typical BM histopathology for AP was described before the TKI treatment era. Following the start of the TKI era, the criteria were modified considering the therapy. Cases responding to TKI treatment are characterized by normalization of the cellular composition of the bone marrow as demonstrated in Figures 21$2 \mathrm{M}$. Abnormal megakaryocytes associated with marked reticulin or collagen fibrosis in accordance with typical AP-CML could be present (Figure 2K). The AP criteria are listed below [4].

- The presence of $t(9 ; 22)(q 34.1 ; q 11.2)$ or BCR-ABL1 (via molecular biology or karyotype analyses) together with genomic cytogenetic evolution and/or TKI resistance.

- Genomic evolution may include second $\mathrm{Ph}^{*}$, trisomy 8, isochromosome $17 q$, trisomy 19 , complex karyotype, or $3 q 26.2$ abnormalities.

- Persistent or increasing abnormal blood counts despite TKI treatment (leukocytosis $(>10 \times 109 / \mathrm{L})$, thrombocytosis (>1000x109/L), or thrombocytopenia $(<100 \times 109 / \mathrm{L})$ unrelated to therapy, 20\% or more basophils, 10\%-19\% blasts)

- Persistent or increasing splenomegaly.

- Occurrence of clinically significant driver mutations in BCRABL1 during TKI therapy (particularly T315I).

- Additional clonal chromosomal abnormalities such as trisomy 8 , isochromosome $17 q$, trisomy 19 , or any new entity of complex karyotype and 3q26.2 abnormalities or any new chromosomal 
abnormality in BCR-ABL fusion-positive cells occurring during TKI treatment are the accepted criteria

There are also provisional response criteria to TKI treatment as described in the 2016 WHO classification. These are: 1-
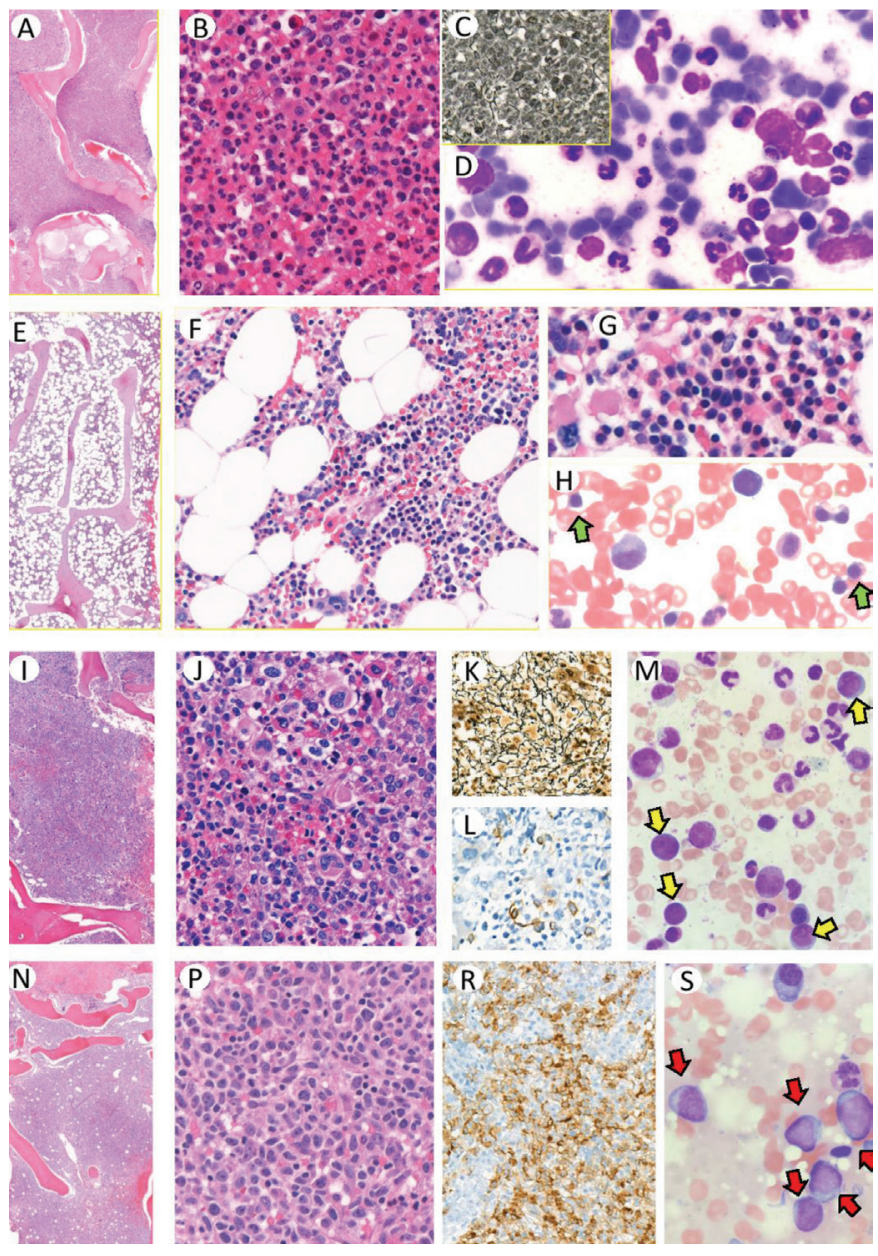

Figure 2. Bone marrow biopsy in chronic phase (CP) $\mathrm{CML}$ is usually hypercellular with $100 \%$ cellularity (A). The bone marrow cells are almost all composed of mature granulocytes and their precursors (B). Reticulin could be seen, especially in the cases with increased megakaryocytes, but usually does not increase (C). Bone marrow aspirate is hypercellular, composed of maturing granulocytic precursors with striking decrease in other precursors (D). Cellularity decreases in the bone marrow of responders to TKI treatment $(E, F)$. The islands of erythroid precursors and megakaryocytes as well as the granulocytic series reflect the normal composition (G). Aspirate smears can also reflect the normal cellular composition with erythroid precursors $\left(H_{\text {; }}\right.$ green arrows). Accelerated phase (AP) CML is characterized by increased blasts of <10\%-19\% and/or megakaryocytes (I, J). Increase in megakaryocyte population promotes reticulin fibrosis (K). Immunohistochemistry is helpful, especially for demonstrating blasts by CD34 staining (L). Blasts on bone marrow aspirates are scattered between myeloid precursors ( $M$; yellow arrows). The blasts are the dominant cellular component in the bone marrow of blastic phase (BP) CML (N, P). Presence of strikingly increased blasts could be demonstrated by CD34 immunohistochemistry (R). On bone marrow aspirate smears, blastic cells are also dominant (S; red arrows).
Failure to achieve complete response to the TKI treatment or hematological resistance; 2- Any hematological, cytogenetic, or molecular indications of resistance to TKI treatment; 3Occurrence of two or more mutations in the BCR-ABL fusion gene during TKI therapy [4].

\section{Blastic Phase CML}

Typical BM histopathology is presented in Figures $2 \mathrm{~N}-2 \mathrm{~S}$ with increased blastic infiltration in accordance with the typical BPCML clinical presentation. The relevant criteria follow [4].

- The presence of $t(9 ; 22)(q 34.1 ; q 11.2)$ or BCR-ABL1 (via molecular biology or karyotype analyses) together with genomic cytogenetic evolution and/or TKI resistance.

- Genomic evolution may include second $\mathrm{Ph}^{*}$ chromosome, trisomy 8 , isochromosome $17 q$, trisomy 19 , complex karyotype, or 3q26.2 abnormalities.

- The presence of at least 20\% blasts in the peripheral blood and/or BM or the presence of extramedullary blastic infiltration in any organ or tissue

- Persistent or increasing splenomegaly.

\section{Frontline Strategies for CML Patients}

TKI drug treatment should be initiated as soon as possible in patients newly diagnosed with CML. The aim of chronic TKI therapy in CML is the restoration of normal hematopoiesis instead of the neoplastic BCR-ABL1-induced myeloid neoplastic proliferation and the prevention of BCR-ABL1-associated genomic instability [8]. Distinct TKI frontline strategy pathways may be chosen to obtain long-term treatment end-points in the personalized treatment of de novo CML. Patient age, CML risk (based on Sokal, Euro/Hasford, EUTOS, and ELTS scoring systems), comorbidities, and the long-term aim of the TKI treatment (mainly prevention of disease progression with life-long TKI drug administration or treatment-free remission) are the main cornerstones for choosing the frontline TKI strategy in CML $[2,9]$.

Pathway 1 (Imatinib as the Frontline TKI for CML): Treatment with oral generic imatinib mesylate at $400 \mathrm{mg}$ daily can be prescribed for any patient with CML as the initial therapy. Switching to a second-generation TKI may be considered in the case of resistance or intolerance during the CML followup period. The rational reasons for choosing this path are pharmacoeconomy, better tolerability, and less toxicity of imatinib with regard to second-generation TKIs. Furthermore, there is no difference of frontline dasatinib/nilotinib/bosutinib compared to imatinib in terms of survival [2].

Pathway 2 (Second-Generation TKI as the Frontline Drug for CML): Second-generation TKIs (nilotinib, dasatinib, bosutinib) may be administered to patients at high Sokal disease risk 
of CML for the prevention of disease progression and blastic crisis. The determination of disease risk may be defined using the Sokal, Euro/Hasford, EUTOS, or ELTS scoring systems [10]. The rationale for this path is the prevention of disease progression, accelerated disease, and blastic crisis in highrisk patients. CML patients with higher percentages of blasts, basophils, and eosinophils and those with thrombocytosis, BM fibrosis, and massive splenomegaly are candidates for frontline second-generation TKI therapy [11]. Relatively young CML patients representing the target subpopulation for treatmentfree remission (TFR) should also be selected for the frontline nilotinib or dasatinib approach. However, there is no overall survival advantage between frontline imatinib and secondgeneration TKI approaches $[12,13,14]$. Therefore, imatinib 400 mg treatment shall be chosen for patients with drug/diseaseassociated comorbidities, for whom TFR is not a target [2].

In clinical practice, any TKI (imatinib, nilotinib, bosutinib, or dasatinib) as frontline therapy can be chosen with the optimization of the dosage with regard to the individual disease/patient characteristics, life expectancy, lifestyle, and comorbidities. TKI dosages (for example, imatinib 300 vs. 400 vs. $600 \mathrm{mg}$; dasatinib 50 vs. 100 vs. $140 \mathrm{mg}$; nilotinib 600 vs. $800 \mathrm{mg}$; ponatinib $15 \mathrm{mg}$ vs. $30 \mathrm{mg}$; bosutinib $300 \mathrm{mg}$ vs. 500 $\mathrm{mg}$ ) could be tailored based on the tolerability, side effects, and BCR-ABL1 levels of the CML patients. The doses of TKIs shall be adopted based on the phase of CML and the line of TKI therapy. Lower starting TKI doses for the sake of tolerability should be titrated up to the standard doses in order to get hematological, cytogenetic, and molecular responses with the observation of toxicity, compliance, and tolerability. The rationale for the TFR path, i.e. frontline second-generation TKIs, is to obtain faster and deeper molecular responses including MR4.5 for TKI drug cessation $[14,15]$. The EURO-SKI trial was performed with molecular responders of MR4 with TKI-free long-term remissions, representing an advantage of survival without TKI toxicities, which may be referred to as "functional cure" [16]. Although the most significant literature experience with TKI discontinuation is with imatinib, patients with two-year administration of second-generation TKIs and a two-year duration of MR4.5 are ideal candidates for TKI drug discontinuation $[2,16,17]$.

The response to TKI drug treatment in a patient with CML must be monitored to check for full hematological (CHR), complete cytogenetic (CCyR), and major molecular (MMR) remissions regardless of the path that has been chosen. The clinicobiological signs of normal hematopoiesis replacing $\mathrm{Ph}^{*}(+)$ myeloid neoplasia should be investigated. Next-generation molecular analyses [18] may be incorporated in the follow-up of CML patients to search for genomic stability of the disease. Current disease guidelines such as those of the ELN or NCCN require CHR within the first month, CCyR within the first year, and MMR within 18 months of TKI therapy. BCR-ABL1 of less than 10\% within the first 3 months after TKI is a very good prognostic sign called early molecular response (EMR). However, there is little evidence that switching to a second-generation TKI in the absence of EMR might produce better disease outcomes and prevention of disease progression $[19,20]$. Preliminary results of the DASCERN study implied that CML patients without EMR to imatinib at 3 months who switched to dasatinib had a significantly increased rate of MMR at 12 months when compared to patients receiving imatinib mesylate. Longer follow-up duration is certainly required to assess the impact of early switching of dasatinib at 3 months on the overall survival of patients [21].

Long-term adverse events associated with the chronic usage of TKI drugs described by the ELN [22] represent an important emerging challenge in everyday clinical practice for CML. Side effects of TKIs are generally mild to moderate and easy to manage in the middle periods of CML therapy [22]. Provisional discontinuation of the drug may be a choice in the case of serious adverse events. Close attention should be paid to drug-drug interactions [23]. Cardiovascular toxicity with ponatinib and nilotinib, pulmonary toxicity with dasatinib, and gastrointestinal/metabolic toxicities with bosutinib and nilotinib may require specific follow-up strategies for early adverse event detection and proper clinical management [24]. If properly managed, TKI therapies are well tolerated with improvement of the drug-related symptoms in due course with a few dose reductions or short drug holidays [25].

\section{Salvage Strategies in CML Patients}

Salvage strategies in CML mainly depend on the alternative unused TKIs and allografting if all of the TKIs were used with a T315I mutation. Decision-making in multi-TKI-resistant CML should rely on the type of first-line treatment, type of resistance (TKI mutation, TKI failure, TKI intolerance, TKI incompliance), phase of disease, and transplant risk score of the patient. Before the consideration of TKI alteration during life-time management of $\mathrm{CML}$, drug dose adjustments, such as TKI dose decrements in the event of adverse events and increments in the presence of insufficient BCR-ABL1 control, shall be performed. The optimal salvage therapeutic strategy for CML will avoid both over- and under-treatment. CML over-treatment may be described as aggressive clinical intervention. For instance, the early/inappropriate decision to apply a very risky hematopoietic stem cell transplantation (HSCT) in a CML patient receiving a given second-generation TKI and exhibiting inadequate response, in which a thirdgeneration TKI or dose increments would produce a better outcome, requires careful consideration. On the other hand, the inability to detect warning signs of relapse/resistance in follow-up resulting in TKI failure and/or blastic crisis may also be considered as inappropriate management. $\mathrm{ABL}$ mutations of T315I, Y253H, E255K, E255V, F359V, F359C, and F359l are 
poorly sensitive to nilotinib and T315I, T315A, F317L, F317V, F317I, F317C, and V299L are the mutations poorly sensitive to dasatinib. Ponatinib is the only TKI for T315I before HSCT. The most challenging situations in patients with $\mathrm{CML}$ are resistance to all available TKIs in patients who inability to undergo transplantation, or recurrence after HSCT, especially into blastic crisis [26]. The fourth-generation drug asciminib, a specific TKI targeting the BCR-ABL1 myristoyl-binding site, an allosteric regulatory domain, and PF-114 mesylate [27], have the potential to treat patients with resistance to ATP-binding-site TKIs, including T315I [28,29]. CML leukemic stem cells expressing IL-1RAP can be targeted by CAR-T cells (chimeric antigen receptor-engineered T Iymphocytes) [30]. Manipulations of CML stem cells [31], neoplastic bone marrow niche trafficking control [32], and the CRISPR/Cas9 system with nanocarriers [33] seem to be future research areas in the field of CML therapy.

\section{Ethics}

Informed Consent: There is no patient presentation or patient information in the article.

\section{Authorship Contributions}

Surgical and Medical Practices: 0.і.; Concept: 0.і.; Design: 0.i.; Data Collection or Processing: I.K.; Analysis or Interpretation: I.K.; Literature Search: I.C.H.; Writing: I.C.H.

Conflict of Interest: The authors declare that they have no conflict of interest.

Financial Disclosure: The authors declared that this study received no financial support.

\section{References}

1. Sahin F, Saydam G, Comert M, Uz B, Yavuz AS, Turan E, Yönal I, Atay H, Keltikli E, Turgut M, Pehlivan M, Akay MO, Gürkan E, Paydaş S, Kahraman S, Demirkan F, Kırkızlar O, Akpınar S, Pamuk GE, Demir M, Ozbaş HM, Sönmez M, Gültürk M, Salihoğlu A, Eşkazan AE, Ar C, Haydaroğlu Şahin H, Ongören S, Başlar Z, Aydın Y, Yenere MN, Tüzüner N, Ferhanoğlu B, Haznedaroglu IC, Ilhan 0, Soysal T. Turkish Chronic Myeloid Leukemia Study: Retrospective Sectional Analysis of CML Patients. Turk J Hematol 2013;30:351-358.

2. Aladağ $E$, Haznedaroğlu ic. Current perspectives for the treatment of chronic myeloid leukemia. Turk J Med Sci 2019;49:1-10.

3. Haznedaroglu IC. Current concerns of undertreatment and overtreatment in chronic myeloid leukemia based on European LeukemiaNet 2013 recommendations. Expert Opin Pharmacother. 2013;14:2005-2010.

4. Arber DA, Orazi A, Hasserjian R, Thiele J, Borowitz MJ, Le Beau MM, Bloomfield CD, Cazzola M, Vardiman JW. The 2016 revision to the World Health Organization classification of myeloid neoplasms and acute leukemia. Blood 2016;127:2391-2405.

5. Nicolini FM, Etienne $G$, Huguet $F$, Guerci-Bresler A,Charbonnier $A$, Escoffre-Barbe M, Dubruille V, Johnson-Ansah H, Legros L, Coiteux V, Cony-Makhoul $\mathrm{P}$, Lenain $\mathrm{P}$, Roy L, Rousselot $\mathrm{P}$, Guyotat D, Lanotto JC, Gardembas $M$, Larosa $F$, Caillot $D$, Turlure $P$, Courby $S$, Quittet $P$, Hermet E, Ame S, Lapusan S, Verane Schwiertz, Pharm D, Morisset S, Etienne $M$, Rea D, Dulucq S,Mahon FX. Nilotinib Versus Nilotinib Combined to Pegylated-Interferon Alfa 2a in First-Line Chronic Phase Chronic Myelogenous Leukemia Patients. Interim Analysis of a Phase III Trial. Blood 2017;130(Suppl 1):899.

6. Testoni N, Marzocchi G, Luatti S, Amabile M, Baldazzi C, Stacchini M, Nanni M, Rege-Cambrin G, Giugliano E, Giussani U, Abruzzese E, Kerim S, Grimoldi MG, Gozzetti A, Crescenzi B, Carcassi C, Bernasconi P, Cuneo A, Albano F, Fugazza G, Zaccaria A, Martinelli G, Pane F, Rosti G, Baccarani M. Chronic myeloid leukemia: a prospective comparison of interphase fluorescence in situ hybridization and chromosome banding analysis for the definition of complete cytogenetic response: a study of the GIMEMA CML WP. Blood 2009;114:4939-4943.

7. Shanmuganathan N, Hughes TP. Molecular monitoring in CML: how deep? How often? How should it influence therapy? Hematology Am Soc Hematol Educ Program 2018;2018:168-176.

8. Saglio $G$, Jabbour E. First-line therapy for chronic phase CML: selecting the optimal BCR-ABL1-targeted TKI. Leuk Lymphoma 2018;59:1523-1538.

9. Mahon FX, Boquimpani C, Takahashi N, Benyamini N, Clementino NCD, Shuvaev V. Long-term treatment-free remission (TFR) in patients (pts) with chronic myeloid leukemia in chronic phase (CML-CP) after stopping second-line (2L) nilotinib: ENESTop 144-wk results. J Clin Oncol 2018;36.

10. Uz B, Buyukasik $Y$, Atay $H$, Kelkitli E, Turgut M, Bektas O, Eliacik E, Isik A, Aksu S, Goker H, Sayinalp N, Ozcebe OI, Haznedaroglu IC. EUTOS CML prognostic scoring system predicts ELN-based 'event-free survival' better than Euro/Hasford and Sokal systems in CML patients receiving front-line imatinib mesylate. Hematology 2013;18:247-252.

11. Eliacik E, Isik A, Aydin C, Uner A, Aksu S, Sayinalp N, Demiroglu H, Goker H, Buyukasik Y, Ozcebe 0, Haznedaroglu IC. Bone marrow fibrosis may be an effective independent predictor of the 'TKI drug response level' in chronic myeloid leukemia. Hematology 2015;20:392-396.

12. Kantarjian $H$, Pasquini $R$, Levy $V$, Jootar $S$, Holowiecki J, Hamerschlak $N$, Hughes T, Bleickardt E, Dejardin D, Cortes J, Shah NP. Dasatinib or highdose imatinib for chronic-phase chronic myeloid leukemia resistant to imatinib at a dose of 400 to 600 milligrams daily: two-year follow-up of a randomized phase 2 study (START-R). Cancer 2009;115:4136-4147.

13. Kantarjian HM, Hochhaus A, Saglio G, De Souza C, Flinn IW, Stenke L, Goh YT, Rosti G, Nakamae H, Gallagher NJ, Hoenekopp A, Blakesley RE, Larson RA, Hughes TP. Nilotinib versus imatinib for the treatment of patients with newly diagnosed chronic phase, Philadelphia chromosome-positive, chronic myeloid leukaemia: 24-month minimum follow-up of the phase 3 randomised ENESTnd trial. Lancet Oncol 2011;12:841-851.

14. Saydam G, Haznedaroglu IC, Kaynar L, Yavuz AS, Ali R, Guvenc B, Akay OM, Baslar Z8, Ozbek U, Sonmez M, Aydin D, Pehlivan M, Undar B, Dagdas S, Ayyildiz O, Akin G, Dag IM, Ilhan O. Frontline nilotinib treatment in Turkish patients with Philadelphia chromosome-positive chronic Myeloid Leukemia in chronic phase: updated results with 2 years of follow-up. Hematology 2018:23:771-777.

15. Saydam G, Haznedaroglu IC, Kaynar L, Yavuz AS, Ali R, Guvenc B, Akay OM, Baslar Z, Ozbek U, Sonmez M, Aydin D, Pehlivan M, Undar B, Dagdas S, Ayyildiz O, Akkaynak DZ, Dag IM, Ilhan 0. Outcomes with frontline nilotinib treatment in Turkish patients with newly diagnosed Philadelphia chromosome-positive chronic myeloid leukemia in chronic phase. Expert Opin Pharmacother 2016;17:1851-1818.

16. Saussele S, Shah N, Garcia-Gutierrez JV, Jimenez-Velasco A, Larson S, Rea $D$, et al. Treatment-free remission (TFR) in patients (pts) with chronicphase chronic myeloid leukemia (CML-CP) and stable deep molecular response (DMR) discontinuing dasatinib (DASFREE). Oncology Research and Treatment 2018;41:138-9.

17. Mahon FX, Boquimpani C, Kim DW, Benyamini N, Clementino NCD, Shuvaev $V$, Ailawadhi $S$, Lipton JH, Turkina AG, De Paz R, Moiraghi B, Nicolini $F E$, Dengler J, Sacha T, Takahashi N, Fellague-Chebra R, Acharya S, Wong $S$, Jin $Y$, Hughes TP.Treatment-Free Remission After Second-Line Nilotinib Treatment in Patients With Chronic Myeloid Leukemia in Chronic Phase: Results From a Single-Group, Phase 2, Open-Label Study. Ann Intern Med. 2018;168:461-470. 
18. Soverini $S$, Bavaro $L$, Martelli $M$, De Benedittis $C$, lurlo $A$, Orofino $N$, Intermesoli $T$, Bona ED, Caocci $G$, Attolico I, Binotto $G$, Bocchia $M$, Angelucci E, Sgherza N, Luciano L,Mignone F, Pileri SF, Martinelli G, Cavo M. Compound BCR-ABL1 Kinase Domain Mutants: Prevalence, Spectrum and Correlation with Tyrosine Kinase Inhibitor Resistance in a Prospective Series of Philadelphia Chromosome-Positive Leukemia Patients Analyzed By Next Generation Sequencing. Blood 2018;132(Suppl 1):789.

19. Baccarani M, Deininger MW, Rosti G, Hochhaus A, Soverini S, Apperley $J F$, Cervantes F, Clark RE, Cortes JE, Guilhot F, Hjorth-Hansen H, Hughes TP, Kantarjian HM, Kim DW, Larson RA, Lipton JH, Mahon FX, Martinelli G, Mayer J, Müller MC, Niederwieser D, Pane F, Radich JP, Rousselot $P$, Saglio G, Saußele S, Schiffer C, Silver R, Simonsson B, Steegmann JL, Goldman $J M$, Hehlmann R. European LeukemiaNet recommendations for the management of chronic myeloid leukemia: 2013. Blood 2013;122:872-884.

20. Baccarani M, Pane F, Rosti G, Russo D, Saglio G. Chronic myeloid leukemia: room for improvement? Haematologica 2017;102:1131-1133.

21. Cortes JE, Jiang O, Wang J, Weng J, Zhu H, Xiaoli L, Hochhaus A, Kim DW, Radich J, Savona MR, Regueira PM, Sy 0, Gurnani R, Saglio G. Dasatinib Versus Imatinib in Patients (Pts) with Chronic Myeloid Leukemia in Chronic Phase (CML-CP) Who Have Not Achieved an Optimal Response to 3 Months of Imatinib Therapy: Dascern. Blood 2018;132(Suppl 1):788.

22. Steegmann JL, Baccarani M, Breccia M, Casado LF, Garcia-Gutierrez V, Hochhaus A, Kim DW, Kim TD, Khoury HJ, Le Coutre P, Mayer J, Milojkovic D, Porkka K, Rea D, Rosti G, Saussele S, Hehlmann R, Clark RE. European LeukemiaNet recommendations for the management and avoidance of adverse events of treatment in chronic myeloid leukaemia. Leukemia 2016;30:1648-1671.

23. Reff MJ, Shillingburg A, Shah B, Elder C, Prescott H, Kennerly-Shah J. Frontline use of tyrosine kinase inhibitors in chronic phase chronic myeloid leukemia: Practice considerations. J Oncol Pharm Pract 2020;26:156-174.

24. Medeiros BC, Possick J, Fradley M. Cardiovascular, pulmonary, and metabolic toxicities complicating tyrosine kinase inhibitor therapy in chronic myeloid leukemia: Strategies for monitoring, detecting, and managing. Blood Reviews 2018;32:289-299.

25. Zulbaran-Rojas A, Lin HK, Shi QL, Williams LA, George B, Garcia-Manero G, Jabbour E, O'Brien S, Ravandi F, Wierda W, Estrov Z, Borthakur G, Kadia $\mathrm{T}$, Cleeland C, Cortes JE, Kantarjian H. A prospective analysis of symptom burden for patients with chronic myeloid leukemia in chronic phase treated with frontline second- and third-generation tyrosine kinase inhibitors. Cancer Med 2018;7:5457-5469.

26. Uz B, Bektas O, Eliacik E, Goker H, Erbilgin Y, Sayitoglu M, Aksu S, Buyukasik Y, Ozcebe 0, Haznedaroglu IC. Allografting for Bosutinib, Imatinib, Nilotinib,
Dasatinib, and Interferon Resistant Chronic Myeloid Leukemia without ABL Kinase Mutation. Case Rep Hematol 2011;2011:263725.

27. Turkina AG, Vinogradova O, Lomaia E, Shatokhina E, Shukhov O, Chelysheva E, Livio Pagano L, Criscuolo M, Bonifacio M, Scaffidi L, Sica S, Sorà F, Maino E, Rondoni M, Laginestra MR, Lunghi F, Ermacora A, D'adda M, Gugliotta G, Castagnetti F, Rosti G, Papayannidis C, Curti A, Miggiano MC, Galimberti S, Percesepe A, Stagno F, Sancetta R, Annunziata M, Falzetti F, Capodanno I, Pregno P,Maffioli M, Nemchenko I, Anna Petrova A, Bykova A, Zaritskey A, Siordia N, Shikhbabaeva D, Shuvaev V, Cortes JE, Gale RP,Baccarani M, Ottmann OG, Mikhailov I, Novikov F, Shulgina V, Chilov G. Phase-1 Study of PF-114 Mesylate in CML Failing Prior Tyrosine Kinase-Inhibitor Therapy. Blood 2018;132(Suppl 1):790.

28. Mauro MJ, Lang F, Kim DW, Cortes JE, Hughes TP, Hochhaus A, Minami H, Boquimpani C, Minami Y, Breccia M, Goh YT, Ottmann O, Sondhi M, Hois $S$, Bédoucha V, Perraud K, Réa D,DeAngelo DJ. Clinical Development of Asciminib (ABL001): A Randomized Phase 3 Study of Asciminib vs Bosutinib in Patients with Chronic Myeloid Leukemia (CML). Clin Lymphoma Myeloma Leuk 2018;18:S223-S.

29. Schoepfer J, Jahnke W, Berellini G, Buonamici S, Cotesta S, Cowan-Jacob SW, Dodd S, Drueckes P, Fabbro D, Gabriel T, Groell JM, Grotzfeld RM, Hassan AQ, Henry $C$, lyer $V$, Jones $D$, Lombardo $F$, Loo A, Manley PW, Pellé $X$, Rummel G, Salem B, Warmuth M, Wylie AA, Zoller T, Marzinzik AL, Furet P. Discovery of Asciminib (ABL001), an Allosteric Inhibitor of the Tyrosine Kinase Activity of BCR-ABL1. J Med Chem 2018;61:8120-8135.

30. Warda W, Larosa F, Neto Da Rocha M, Trad R, Deconinck E, Fajloun Z, Faure C, Caillot D, Moldovan M, Valmary-Degano S, Biichle S, Daguindau E, Garnache-Ottou F, Tabruyn S, Adotevi O, Deschamps M, Ferrand C. CML hematopoietic stem cells expressing IL-1RAP can be targeted by chimeric antigen receptor (CAR)-engineered T cells. Cancer Res 2019;79:663-675.

31. Ozdemir ZN UA, Toprak SK, Topcuoglu P, Dalva K, Ilhan 0. Investigating the Presence of Chronic Myeloid Leukemia Leukemic Stem Cells in Patients with Tyrosine Kinase Inhibitors Who Achieved Cytogenetic / Molecular Response. Hem Disease Therapies 2018;3:16-19.

32. Zhang B, Nguyen LXT, Li L, Zhao D, Kumar B, Wu H, Lin A, Pellicano $F$, Hopcroft L, Su YL, Copland M, Holyoake TL, Kuo CJ, Bhatia R, Snyder DS, Ali $H$, Stein AS, Brewer C, Wang H, McDonald T, Swiderski P, Troadec E, Chen CC, Dorrance A, Pullarkat V, Yuan YC, Perrotti D, Carlesso N, Forman SJ, Kortylewski M, Kuo YH, Marcucci G. Bone marrow niche trafficking of miR-126 controls the self-renewal of leukemia stem cells in chronic myelogenous leukemia. Nat Med 2018;24:450-462.

33. Liu Y, Zhao G, Xu CF, Luo YL, Lu ZD, Wang J. Systemic delivery of CRISPR/ Cas9 with PEG-PLGA nanoparticles for chronic myeloid leukemia targeted therapy. Biomaterials Science 2018;6:1592-1603. 